\title{
Factors Affecting Mathematics Performance of Junior High School Students
}

\author{
Emerson Peteros ${ }^{1}$, Antonietta Gamboa ${ }^{2}$, Jonathan O. Etcuban ${ }^{1 *}$, Aahron Dinauanao ${ }^{3}$, Regina Sitoy ${ }^{1}$, \\ Redjie Arcadio ${ }^{1}$
}

${ }^{1}$ Cebu Technological University, Cebu City, PHILIPPINES

${ }^{2}$ Department of Education - Province of Cebu, Cebu, PHILIPPINES

${ }^{3}$ University of Southern Philippines Foundation, Cebu City, PHILIPPINES

*CORRESPONDENCE: $\$ joetcuban@gmail.com

\begin{abstract}
Self-concept in mathematics can be defined as student ratings of their skills, ability, enjoyment, and interest in mathematics is seen as an essential factor in their achievement in math. This study assessed the self-concept and academic performance in Math of the Grade 10 students of a public national high school, Cebu, Philippines. The study employed descriptive correlational research. One hundred eighty-three respondents were asked to answer a survey questionnaire in order to measure their self-concept. Their academic performances were assessed using their grades in Math. The assembled information was dealt with measurably utilizing recurrence, percentage, weighted mean, t-test, and Pearson $r$. Results revealed that they had a moderate level of selfconcept towards learning Mathematics. No gender difference was found on the self-concept of the respondents, but there was a significant relationship between self-concept and the respondents' academic performance in Mathematics. Hence, a Math performance enhancement plan is highly recommended for adoption and evaluation.
\end{abstract}

Keywords: academic performance, self-concept, learning mathematics

\section{INTRODUCTION}

In any culture of the different countries around the world, it is a widespread stereotype that Mathematics is linked among adult males, with the perception that "Math is for males," which resulted to the underrepresentation of women in the field of science, engineering and mathematics (Cvencek et al., 2015). This stereotype has been influential in the educational interests and career choices of children (Cheryan et al., 2015). Moreover, the perception of the society about gender on the Math skills among boys and girls leads to the difference in the identification of their skills and interests at their very young ages (Cvencek et al., 2011). This could also probably mediate their learning in the subject by influencing their interests and perceptions towards their abilities in performing tasks related to the subject (Beilock et al., 2010).

Students' self-perceptions about their academic abilities are vital in their effort to adjust with their school tasks and responsibilities because these perceptions could influence the extent of efforts students to exert for their school tasks (Farrington et al., 2012; Pajares \& Schunk, 2001). Students who perceive that they are skillful in a particular subject would likely to perform well in that field than those who perceive to have low skills (Correll, 2001; Hannover \& Kessels, 2004). The academic performance of students who have a lesser interest in doing the task would be negatively affected (Pintrich, 2000; Ryan \& Patrick, 2001). On the other hand, students who have high self-concept on a particular subject likely aims to perform well in whatever

Article History: Received 2 July $2019 \bullet$ Revised 31 July $2019 \bullet$ Accepted 31 July 2019

(C) 2020 by the authors; licensee Modestum Ltd., UK. Open Access terms of the Creative Commons Attribution 4.0 International License (http://creativecommons.org/licenses/by/4.0/) apply. The license permits unrestricted use, distribution, and reproduction in any medium, on the condition that users give exact credit to the original author(s) and the source, provide a link to the Creative Commons license, and indicate if they made any changes. 


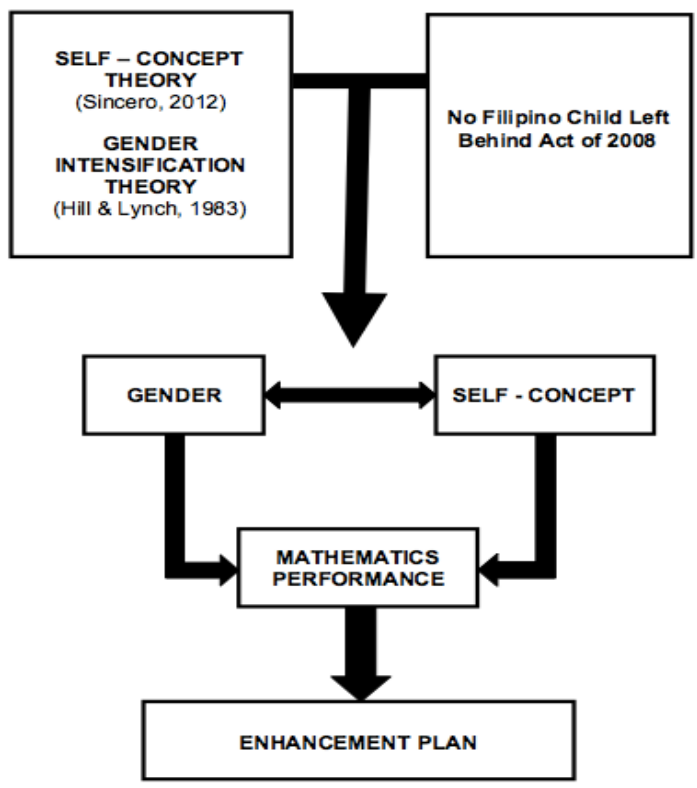

Figure 1. Conceptual Framework of the Study

related tasks are given to them. In turn, this brings positive effects on their performance in the subject. Thus, a high academic self-concept directly relates to better academic achievement (Khalaila, 2015).

Consequently, most researchers had reported that boys have more positive self-concept than girls in Mathematics (Kamoru \& Ramon, 2017). It was also observed that boys outperform girls in standardized test in Math, but girls perform better when specific tests are given to measure their knowledge and understanding on the topics discussed (Ganley et al., 2013; Spencer et al., 1999). Several established results which proved that boys perform better in Math exist, but still, this area should be explored further to affirm or contradict the previous findings presented in this literature.

In the Philippines, few kinds of literature discuss gender differences in the self-concept and performance of the students in mathematics. It is interesting to explore whether the findings of the previous studies are consistent or reflective with the students in this country. According to Capuno et al. (2019) that Filipino students' performance in Math needs to be improved as reflected in the 2016-2017 Global Competitiveness Report; in this, the Philippines ranked $79^{\text {th }}$ out of the 138 participating countries in terms of the quality of Science and Math education. This report is consistent with the Department of Education's (DepEd) National Achievement Test (NAT) results, in which the Mean Percentage Score in Mathematics was 48.63\% a score below the 50 percent requirement of DepEd. It is essential that factors affecting the performance of the students in Math are explored in order to address these concerns, neglecting to address these problems will worsen the situation of the country's educational development. To address these problems, an assessment of the status of the problem must start from the school level.

The students were observed to have adopted the societal stereotype that boys perform better in Math than girls. This is evident when tasks are given to the students, yet most girls would be hesitant to participate; they prefer that boys perform the tasks given to them. Other than that, if group activities are given, girls usually refuse to accept the responsibility of doing the activities assigned to them. Boys are usually delegated to do the tasks for the group. In this connection, boys are observed to be more confident in sharing their ideas and solutions to the class whenever they are asked to discuss their answers in front. If left unattended, this scenario will promote the perceptions that girls are inferior to boys when it comes to mathematics skills.

\section{FRAMEWORK}

This study is anchored on the Self-concept theory, as discussed by Sincero (2012), which mentioned three aspects of self-concept. First, Self-concept is learned. Individuals develop the self-concept and can be changed, which the surrounding environment affects (Zimmerman, 2013). This is a result of the contacts with different individuals through socialization. Likewise, when students observed from the societal stereotype that boys are better than girls in Math, they tend to develop the concept based on what is perceived by society to be true to them. 
Second, the self-concept is organized. One may look at him in different ways, but there is one perception that will help the individual organize these perceptions. When beliefs of individuals are consistent with what he is, there is a tendency that this belief would stay on the person and thus it would be tough to change this perception though it is possible to change this. Students who think that they are useful in Math and perform well in the subject would likely develop a positive self-concept towards the subject. However, when one finds Math a problematic subject and results of exams and performances are weak, they would likely to think that they could not perform well in the subject. The stereotyping on the skills of the students could reinforce this thinking.

Third, the self-concept is dynamic. As individuals experience different situations in life, his beliefs may change depending upon what kind of situation he experiences and how they respond to these experiences. The reactions of an individual are dependent on how they perceive themselves in a given situation wherein there is the tendency to let go of things that are not consistent to them and hold on to the things that would reflect oneself and helpful in developing a more favorable personal being. The students' experience in school is significant in molding their self-concept towards any academic subject, especially in subjects wherein most students find this subject challenging. Allowing the students to have a pleasant experience in Math would help eliminate the gender gap between the students' performance in Math. This could also assist in promoting a positive self-concept towards the subject regardless of gender. Teaching strategies that eliminate students' gap in performance could help improve students' performance in school.

Moreover, this study is also anchored on the gender intensification theory by Hill and Linch (1983) as cited in Priess-Groben and Linberg (2018) which suggests that girls and boys experience increased pressure to conform to culturally sanctioned gender roles during adolescence. Individuals form their identity based on their experiences and expectations of the environment from them. Adolescents start to develop such feelings as they socialize with other people. Once they can identify and organize their perceptions on their being, they will try to assess if their perceptions are consistent with whom they are. Societal stereotype plays a significant role in molding the identity of adolescents like the gender-role stereotype, which can affect the academic selfconcept of the students (Cheryan et al., 2015).

High school students tend to develop their own identity in school and act accordingly on what is expected from them. This situation is relevant to the school responsibilities and tasks that students may encounter in school. If students develop their self-concept towards the subject, they will identify their perceived limitations and strengths of the subject. Hence, they perform tasks according to their perceived capabilities. The stereotype that Math is for males are commonly observed in schools (Nosek et al., 2002). In this connection, teachers need to establish strategies that are eliminating gender gaps in terms of the self-concept and performance of the students in Math.

Teachers are responsible in providing students with equal opportunities to learn in school which is stipulated in the "No Filipino Child Left behind Act of 2008" which aimed to protect and promote the right of the citizens to quality education and to take appropriate steps to make such education accessible to all. One way of providing quality education is to provide equal opportunities for children to be educated regardless of sex, ethnicity, race, religion, and the like. Thus, it is necessary that teachers eliminate stratification inside the classroom in order to minimize the individual differences of the students. The goal of the teachers is to allow students to achieve maximum learning inside the classroom by facilitating learning. With the gender differences in Mathematics, learning of the inferior gender will be affected, and similar effects could happen on their counterparts. That is why the teachers can promote healthy competition based on individual skills and abilities and not by groups.

There is literature that explores the variables such as gender, self-concept, and academic performance of the students in Math that are considered in the study, and findings of these studies are discussed here.

According to Tully and Jacobs (2010), the gender gap in Mathematics has been an exciting research topic over the decades because the continuous development of technology could affect women's involvement in terms of career and economic opportunities. Mathematics is perceived to be an essential requirement when one pursues mathematically oriented courses such as Science, Engineering, and Technology in college. However, men still outnumbered women in these areas. This is due to the perception that Math is for males.

Several studies also revealed that there is a consistent gender difference in self-concept wherein males are found to have higher self-concepts in Mathematics than females. This gender differences in academic selfconcept also explain the gender differences in preferred tasks and career choices. This concept explains the gender intensification theory that gender-role become more critical when they conform to the gender-role 
stereotypes in society. Thus, females have a more negative concept on male-related domains such as Mathematics in the same way that males have a negative concept on female-related domains like Arts (Nagy et al., 2010).

Dramanu and Balarabe (2013) cited that self-concept is multifaceted, hierarchical, organized and structured, descriptive and evaluative, stable, and yet increasingly situation specific. Moreover, academic selfconcept is an evaluation of the perception of students based on their experience and interpretation of the events that they experience in school which leads to the formation of specific attitudes, feelings, and perceptions about one's intellectual and academic abilities based on the academic scenario.

In the study of Guay et al. (2010), which aimed to investigate the self-concept of the students, they found that students who have high academic self-concept have higher grades because they are more motivated to perform well in school. However, students who have low self-concept avoid school tasks because they consider these as threats, which led them to have poor performance.

Timmerman et al. (2017) examined the relationship between the Math self-concept and Math achievement of the 108 twelve to 14-year-old students from a secondary school in the Netherlands. They found that there is a significant positive correlation between Math self-concept and achievement of the students in all four domains of Math, such as measurement, relations, numbers, and scale. Furthermore, the regression analysis showed that Math self-concept was significantly accounted for in the variance of Math scores of the students.

Kamoru and Ramon (2017) investigated the relationship between self-concept and Math achievement of 200 senior secondary school students from Ibadan Metropolis using random sampling. Students were asked to answer the 20-item Math Self Concept Questionnaire and took a 30-item multiple choice Math Achievement Test. Results uncovered that there was no noteworthy distinction in gender for Math self-concept. Furthermore, there was a significant positive correlation between the self-concept and the Math achievement of the students. Thus, they suggested that teachers should develop a positive self-concept of the students towards Mathematics and provide a pleasant teaching experience in order to enhance higher self-concept and better performance of the students in Mathematics.

The sex differences of the students in self-concept and academic performance in Math among the Russian High School students, there was a sex difference in the Math achievement of the students were in girls had higher grades compared to boys (Else-Quest et al., 2010). Moreover, according to Preckel et al. (2008) that girls had higher self-concept than boys on Math tests, but boys perform better in the test compared to their counterparts.

Cvencek et al. (2015) studied the gender identity, Math -gender stereotypes, Math self-concepts, and Math achievement of Singaporean elementary students. Students were asked to answer the Child Implicit Association Tests (Child IAT) and the standardized Math achievement test. Results showed that Math selfconcepts were positively related to Math achievement. There was a significant correlation between stronger Math self-concept and stronger Math-gender stereotypes for boys but a weaker Math self-concept for girls. Lastly, Math-gender stereotypes were significantly related to Math achievement.

Dramanu and Balarabe (2013) examined the relationship between self -concept and the academic performance of Junior High School students in Ghana. Students were asked to complete the self-concept questionnaire and answer the Math achievement test. Results uncovered that there was a critical connection between results revealed that there was a significant relationship between self-concept and academic performance of the students. Further, a significant difference between the self-concept of the urban and rural high school students has also observed wherein urban high school students had higher scores.

Lee and Kung (2018) explored the relationship between Math self-concept and Math achievement of the Junior High School Taiwanese students using structural equation modeling. They found that there was a considerable gender contrast concerning the student's Math self-concept and Math achievement. Boys showed a higher self-concept than girls, but girls had higher Math achievement than boys. Similarly, Ajogbeje (2010) investigated the relationship between self-concept and academic achievement of the 450 secondary students in Ekiti State using multiple regression analysis. Results uncovered that there was a critical connection between self-concept and Math achievement. It also revealed that moderate self-concept could predict Math achievement.

The theories and literature that are discussed in this section provide the framework of the conduct in this study. The interplay of gender, self-concept, and Math achievement was also explored to provide meaningful information on the findings of the previous studies regarding these variables. 
Table 1. Distribution of the Respondents

\begin{tabular}{|c|c|c|c|c|c|c|}
\hline \multirow{3}{*}{ Section } & \multicolumn{4}{|c|}{ Gender } & \multirow{3}{*}{ Total } & \multirow{3}{*}{$\%$} \\
\hline & \multicolumn{2}{|c|}{ Male } & \multicolumn{2}{|c|}{ Female } & & \\
\hline & $\mathbf{N}$ & $\mathbf{n}$ & $\mathbf{N}$ & $\mathbf{n}$ & & \\
\hline $\mathrm{A}$ & 8 & 5 & 35 & 20 & 25 & 13.66 \\
\hline B & 46 & 25 & 31 & 17 & 42 & 22.95 \\
\hline $\mathrm{C}$ & 35 & 20 & 36 & 20 & 40 & 21.85 \\
\hline $\mathrm{D}$ & 36 & 20 & 33 & 18 & 38 & 20.77 \\
\hline $\mathrm{E}$ & 44 & 24 & 25 & 14 & 38 & 20.77 \\
\hline Total & & 94 & & 89 & 183 & 100.0 \\
\hline
\end{tabular}

\section{OBJECTIVES OF THE STUDY}

This study assessed the self-concept and academic performance in mathematics of the junior high students of a public national high school, Cebu, Philippines as the basis for a proposed Math performance enhancement plan. It answered the: 1) Profile of the respondents; 2) Level of academic performance of the respondents in mathematics; 3) Level of self-concept of the respondents towards mathematics as learned, organized, and dynamic; 4) Significant mean difference on the self-concept of the respondents based on gender; and 5) Significant relationship between the self-concept and academic performance of the respondents in mathematics.

\section{METHODOLOGY}

This study employed a descriptive-correlational research design, which aimed to determine the relationship between the self-concept and academic performance of the respondents in mathematics. It also considered the difference in the gender difference towards the respondents' self-concept towards mathematics. The respondents were identified using stratified random sampling, and the Slovin's formula was utilized to determine the appropriate number of respondents needed in this study. The data were organized, tallied, summarized, interpreted, and analyzed based on the results of the data gathering.

This study was conducted in a public national high school, which is located in Cebu, Philippines. It opens new opportunities to students who will pursue their Senior High School years. It offers General Academic Strand (GAS), and Technical Vocational \& Livelihood (TVL) specially Shielded Metal Arc Welding (SMAW), which prepares the student for professional preparation and employment later in life. The school has and will still be producing more professionals in various fields.

The focus of this study was the Grade 10 students are exposed to the different concepts in mathematics, which are more complex, compared to the topics they learn during elementary. As the grade level becomes higher, the concepts get more complicated. However, with the K-12 curriculum implementation, concepts in Math are introduced in spiral progression, which means that the concepts are introduced in the lower level with increasing complexity as the students move to the next level. However, this curriculum was newly implemented wherein most teachers are still oriented on the previous curriculum wherein lessons on a specific topic are introduced differently. Teachers are still adjusting on the approach on how to introduce Math lessons in this curriculum.

With this scenario, students could think Math to be more complicated because they are not yet ready to learn the topic. Thus, the student's self-concept of Math could be affected. That is why it is necessary to assess the self-concept of these students in order to take action on the effects of K-12 curriculum towards the students' self-concept in Math. Table 1 presents the distribution of the respondents according to their section in which the percentage of each section that was participating in the study is also indicated.

As reflected in Table 1, there were 25 or 13.66 percent from Section A, 42 or 22.95 percent from Section B, 40 or 21.85 percent from Section C, 38 or 20.77 percent from Section D and 38 or 20.77 percent from Section E. These respondents were identified using stratified random sampling in which gender was used as the stratum and Slovin's formula was used to assure the correct number of respondents who participated in the study.

A survey questionnaire was used to gather the desired data on this study, which consists of two parts. The first part consists of questions that elicit the profile of the respondents in terms of their age, gender, parents' highest educational attainment, and many honors/awards received related to Math. The second part is an 
Table 2. Age and Gender of the Respondents

\begin{tabular}{|c|c|c|c|c|c|c|}
\hline \multirow[b]{2}{*}{ Age (in years) } & \multicolumn{2}{|c|}{ Male $(\mathrm{n}=94)$} & \multicolumn{2}{|c|}{ Female $(n=89)$} & \multicolumn{2}{|c|}{ Total $(\mathrm{N}=183)$} \\
\hline & $\mathbf{f}$ & $\%$ & $\mathbf{f}$ & $\%$ & $\mathbf{f}$ & $\%$ \\
\hline 21 and above & 3 & 1.64 & 1 & 0.54 & 4 & 2.19 \\
\hline $19-20$ & 7 & 3.83 & 3 & 1.64 & 10 & 5.46 \\
\hline $17-18$ & 45 & 24.59 & 22 & 12.02 & 67 & 36.61 \\
\hline $15-16$ & 39 & 21.31 & 63 & 34.43 & 102 & 55.74 \\
\hline Average: & 17.1 & & 16.3 & & 16.7 & \\
\hline
\end{tabular}

adapted questionnaire from Kvedere (2012), which consists of 30 statements describing the Mathematics selfconcept as learned, organized, and dynamic of the students. They were asked to rate each statement as to the level of their agreement on the extent that these statements describe their self-concepts in Math. The instrument is using a five-point Likert scale with responses such as 5-Very High, 4-High, 3-Moderate, 2-Low, and 1-Very Low.

Furthermore, the academic performance of the respondents in mathematics was measured using the average grade from First to Third Quarter. The grades were retrieved with the aid of their subject teacher.

The gathered data underwent systematic procedures of processing to ensure validity and reliability of results. Appropriate statistical tools were used in treating the data using the MS Excel and SPSS software with the assistance of the statistician. Frequency, weighted mean, percentage, t-test, and Pearson $\mathrm{r}$ were used to treat the gathered data.

\section{RESULTS AND DISCUSSIONS}

\section{Profile of the Respondents}

This part illustrates the profile of the respondents as to their age, gender, parents' highest educational attainment, and several honors/awards received related to Math. This profile will help in exploring the relationship between the variables.

The profile of the respondents, particularly their age and gender, are considered to be important in the study. Data on these variables are presented in Table 2.

The respondents are the Grade 10 students whose average age was 16.7 years old. There was 94 or 51.37 percent of the respondents who are male students, while 89 or 48.63 percent are female students whose average age were 17.1 years old and 16.3 years old, respectively. The composition of the respondents has more male students who are older than the female students. In general, most of them were aging from 15 to 16 years old. This is the right age for the Grade 10 students. It means that most of them are at the right age of schooling. However, for those who are older than the other students, they could encounter the effects of attending a school that is older than their peers.

Grissom (2004) found a negative correlation between age and the academic achievement of students in school.

According to Meece et al. (2006) that the job of sexual orientation, informing accomplishment inspiration has a long history in mental and instructive research. The discoveries demonstrate that young ladies' and young men's inspiration related convictions and practices keep on following sexual orientation job generalizations. Young men report more grounded capacity and intrigue convictions in arithmetic and science, though young ladies have more certainty and enthusiasm for language expressions and composing. Sexual orientation impacts are directed by capacity, ethnicity, financial status, and study hall setting.

Parents are considered to influence how their children look at themselves and how they perform in school. The parents' educational attainment is one of the profiles of the respondents that are gathered in this study. Table 3 presents the distribution of the data.

The table showed that most of the parents' educational attainment was at the elementary level only wherein there was 58 or 31.69 percent of the mothers and 64 or 34.97 of the fathers had reached this level only. There was 50 or 27.32 percent of the mothers who are secondary graduate while 33 or 18.03 percent of the fathers reached secondary level. However, there was 16 or 8.74 percent of the mothers who reached college and four or 2.19 percent of them who had finished college while 20 or 10.93 percent of the fathers had reached college and nine or 4.92 percent of them had finished college. In general, the mothers had higher educational attainment compared to the fathers of the respondents. The parents' educational attainment can be the 
Table 3. Parents' Highest Educational Attainment

\begin{tabular}{|c|c|c|c|c|c|c|}
\hline & \multicolumn{2}{|c|}{ Mother $(n=183)$} & \multicolumn{2}{|c|}{ Father $(n=183)$} & \multicolumn{2}{|c|}{ Total $(\mathrm{N}=366)$} \\
\hline Educational Attainment & $\mathbf{f}$ & $\%$ & $\mathbf{f}$ & $\%$ & $\mathbf{f}$ & $\%$ \\
\hline College Graduate & 4 & 2.19 & 9 & 4.92 & 13 & 3.55 \\
\hline College Level & 16 & 8.74 & 20 & 10.93 & 36 & 9.84 \\
\hline Secondary Graduate & 50 & 27.32 & 28 & 15.3 & 78 & 21.31 \\
\hline Secondary Level & 35 & 19.13 & 34 & 18.58 & 69 & 18.85 \\
\hline Elementary Graduate & 20 & 10.93 & 28 & 15.3 & 48 & 13.11 \\
\hline Elementary Level & 58 & 31.69 & 64 & 34.97 & 122 & 33.33 \\
\hline
\end{tabular}

Table 4. Number of Awards and Honors Received by the Respondents

\begin{tabular}{cccc}
\hline Number of Awards and Honors Received & $\mathbf{f}$ & $\mathbf{\%}$ \\
\hline 6 and above & 6 & 3.28 \\
\hline 5 & 4 & 2.19 \\
\hline 4 & 14 & 7.09 \\
\hline 3 & 19 & 10.38 \\
\hline 2 & 15 & 8.20 \\
\hline 1 & 123 & 67.21 \\
\hline
\end{tabular}

Table 5. Performance Level of the Respondents

\begin{tabular}{lccc}
\hline Level & Numerical Rating & f & \% \\
\hline Outstanding & $90-100$ & 13 & 7.10 \\
\hline Very Satisfactory & $85-89$ & 20 & 10.93 \\
\hline Satisfactory & $80-84$ & 52 & 28.42 \\
\hline Fairly Satisfactory & $75-79$ & 97 & 53.01 \\
\hline Did not meet the Expectations & Below 75 & 1 & 0.54 \\
\hline Average : & $\mathbf{8 0 . 0}$ & & \\
\hline
\end{tabular}

motivation of their children to perform better in school and to have higher dreams in their life because parents can serve as the model to their children.

Aside from that, parents can assist their children in school when they have higher educational attainment by sharing their knowledge of the lessons of their children (Delpit, 2006). Having parents that are supportive to their children's school works and activities will help enhance the self-concept of the child because children believe that they can do things in school with the help of their parents (Bandura et al., 2001; Martin \& Jackson, 2002). Particularly in Mathematics, when parents can contribute to the Math-related tasks of their child, this would help builds up a positive self-concept of the child because self-concept is developed through experience.

Academic self-concept is an evaluation of the perception of students based on their experience and interpretation of the events that they experience in school which leads to the formation of specific attitudes, feelings, and perceptions about one's intellectual and academic abilities based on the academic scenario (Zimmerman, 2013).

The respondents' achievements in school that are related to Mathematics can enhance the way they perceive their skills in learning the subject. It is for this reason that awards or honors of the respondents received are accounted for in this study, which is shown in Table 4.

It can be observed that 123 or 67.21 percent of the respondents did not receive any awards or honors that are related to Mathematics. However, 15 respondents received one award, and 19 of them received two awards/honors that are related to the subject. Fourteen respondents received three awards, two respondents who received four awards, and four respondents who received five awards. Interestingly, six respondents received 6 or more awards. It can be understood that most students find the subject difficult, that is why only a few of them received awards related to the subject. Awards and recognition of the achievement of the students will help boost their confidence in school. Like Math, most students have difficulties in learning the subject. So when students receive awards from their achievement in Mathematics, this will enhance their confidence in learning the subject. In this way, students' self-concept about learning the subject will be boosted (Gbollie \& Keamu, 2017).

This portion reveals the results for the performance of the respondents in Mathematics using their average grade in Mathematics for the First to Third Grading. The data are presented in Table 5. 
Table 6. Respondents' Level of Self-Concept

\begin{tabular}{|c|c|c|c|c|}
\hline \multirow{2}{*}{ A. } & \multirow{2}{*}{$\begin{array}{l}\text { Indicators } \\
\text { Learned }\end{array}$} & \multicolumn{3}{|c|}{ Mean StDev Description } \\
\hline & & & & \\
\hline 1. & I learn Mathematics quickly. & 2.97 & 0.791 & Moderate \\
\hline 2. & In my Mathematics class, I understand even the most challenging work. & 2.51 & 0.844 & Low \\
\hline 3. & I have never felt incapable of learning Math. & 2.72 & 0.867 & Moderate \\
\hline 4. & I am good at Mathematics. & 2.68 & 0.805 & Moderate \\
\hline 5. & I am capable of making a good grade in Mathematics. & 2.70 & 0.865 & Moderate \\
\hline 6. & I do extra work to learn Mathematics. & 2.85 & 0.981 & Moderate \\
\hline 7. & Learning Mathematics gives me meaning to learn activities. & 2.97 & 0.954 & Moderate \\
\hline 8. & Even if the work in Mathematics is hard, I can learn it. & 2.72 & 0.91 & Moderate \\
\hline 9. & Every question in Mathematics is answerable. & 2.56 & 0.809 & Low \\
\hline \multirow[t]{2}{*}{10.} & I am sure I can learn the skills taught in Mathematics class well. & 2.75 & 0.878 & Moderate \\
\hline & Overall : & 2.74 & 0.870 & Moderate \\
\hline \multicolumn{5}{|c|}{ B. Organized } \\
\hline 1. & I usually do well in Mathematics. & 2.82 & 0.822 & Moderate \\
\hline 2. & $\begin{array}{l}\text { Mathematics is more enthusiastically for me than for a significant number of my } \\
\text { schoolmates. }\end{array}$ & 2.86 & 0.993 & Moderate \\
\hline 3. & I have dependably accepted that Mathematics is a standout amongst my best subjects. & 2.63 & 1.140 & erate \\
\hline 4. & I get good marks in Mathematics. & 2.67 & 0.892 & Moderate \\
\hline 5. & Mathematics is an easy subject to pass. & 2.27 & 0.878 & Low \\
\hline 6. & Mathematics is worth passing well. & 2.78 & 0.964 & rate \\
\hline 7. & Mathematics help to find a new way & 3.03 & 1.021 & cate \\
\hline 8. & Math, I feel confident that I have done it correctly. & 2.78 & 1.016 & Moderate \\
\hline 9. & It takes me any longer to comprehend mathematics ideas than the average individual. & 2.87 & 0.938 & Moderate \\
\hline & When I have difficulties with Math, I know I can handle them if I try. & 3.15 & 0.960 & Moderate \\
\hline & Overall : & 2.74 & 0.870 & Moderate \\
\hline \multicolumn{5}{|c|}{ C. Dynamic } \\
\hline 1. & I can do practically all the work in Mathematics class if I do not give up. & 3.23 & 0.984 & Moderate \\
\hline 2. & Mathematics improves my understanding of other subjects. & 2.91 & 0.916 & Moderate \\
\hline 3. & Mathematics improves my learning and retention capacities. & 2.93 & 0.959 & Moderate \\
\hline 4. & I feel delighted when answering Mathematics questions. & 2.81 & 1.006 & Moderate \\
\hline 5. & Mathematics is suitable for all students. & 2.92 & 1.097 & Moderate \\
\hline 6. & Mathematics encourages me to apply detailed steps to solve my problems. & 2.98 & 1.027 & Moderate \\
\hline 7. & Mathematics makes me think fast. & 2.81 & 1.026 & Moderate \\
\hline 8. & My present knowledge of mathematical concept is high. & 2.58 & 0.904 & Low \\
\hline 9. & Mathematics is essential in the future. & 3.38 & 1.188 & Moderate \\
\hline \multirow[t]{2}{*}{10.} & I am comfortable in Mathematics. & 2.76 & 1.057 & Moderate \\
\hline & Overall : & 2.93 & 1.016 & Moderate \\
\hline
\end{tabular}

Table 5 reveals that 97 or 53.01 percent of the respondents had reasonably satisfactory performance in mathematics, which is followed by 52 or 28.42 percent of the respondents who had satisfactory performance in the subject. Only 20 or 10.93 percent of them had very satisfactory performance, and 13 or 7.10 percent had outstanding performance in the subject.

There was one of them who did not pass the subject. Generally, the respondents' average grade was 80.0, which means that they had satisfactory performance after the three grading periods. The data show that the respondents' performance in the subject needs to be improved. Problems about learning the subject need to be addressed to improve students' performance, mainly that they were already assessed for the three grading periods, yet their performance needs to be improved. Majority of the respondents had reasonably satisfactory performance, which is not a good sign when it comes to the teaching-learning process, is concerned. This implies that students learned from the subject at a minimal level.

Based on the study of Hyde and Mertz (2009), it indicates that more significant male variability concerning mathematics is not ubiquitous. Instead, its presence correlates with several measures of gender inequality. Thus, it is mostly an artifact of changeable sociocultural factors, not immutable, innate biological differences between the sexes.

\section{Respondents' Level of Self-Concept towards Mathematics}

This section presents the level of self-concept of the respondents, which was assessed in three areas as reflected in the Self-Concept Theory, which discussed that Self-concept is learned, Self-concept is organized, and Self-concept is dynamic. The data are presented in Table 6. 
As seen in Table 6, the respondents had a moderate level of self-concept as learned by them with an overall weighted mean of 2.74 and an overall standard deviation of 0.870 . However, items 2 and 9 with weighted means of 2.51 and 2.56, respectively, signify that the respondents had low self-concept on the perception that they understand Mathematics even the most difficult ones and that every question in Mathematics is answerable. This low level of the respondents' self-concept could be based on their experiences that they were not able to solve severe problems in Mathematics and that they think that not all these problems have answers. On the other hand, students still believe that they can learn Mathematics quickly based on the weighted mean of their responses in item 1 which is 2.97 with a standard deviation of 0.791 in the same way that they think that learning Mathematics gives meaning to their activities. Students find the meaning of their task in the subject, which helps them realize the need to learn the subject.

Self-concept is developed in a person based on the consistency of ones perceived the reality of himself, which is consistent with what he experienced. Thus, this area of self-concept is assessed in which results are reflected in the table.

The level of self-concept of the respondents based on the theory that self-concept is organized. In all these statements, the respondents' perception that when they have difficulties in Mathematics they believe that they can handle their difficulties when they try. This could be due to the respondents' experiences that when they try to solve challenging tasks in Math, they can perform such tasks when they perform those tasks. Moreover, respondents believe that the subject can help them find a new way of finding things, which can be related to their experiences when solving Math problems using their way. However, the respondents do not perceive mathematics as an easy subject to pass with a weighted mean of 2.27 and a standard deviation of 0.878. This implies that Math is a tricky subject.

In general, the respondents had a moderate level of self-concept with an overall weighted mean of 2.79 and an overall standard deviation of 0.962 . The data imply that the self-concept of the respondents based on their belief that they can perform well in the subject when they exert more effort in doing Math-related tasks. However, this self-concept needs to be improved because this could help the respondents develop a positive attitude towards the subject, which can also help in improving the students' academic performance.

The Self-Concept Theory proposed that the self-concept of the individual is dynamic, which means that this could change over time based on the experiences of the individual. The data show that the respondents had a moderate self-concept based on the component of self-concept as dynamic with an overall weighted mean of 2.93 and an overall standard deviation of 1.016. Additionally, the respondents perceived that mathematics is essential in their future, which means that they value the subject in their life because it would be useful in the future. They believe that they can use what they have learned in the subject in their daily living. Respondents also believe that they can almost do all the Math work if they are persistent enough in doing their tasks. Though the respondents have a moderate self-concept, they believe that their knowledge in the subject is not yet enough.

In this study, the respondents' self-concept needs to be improved since students with high self-concept have greater chances of doing their tasks well compared to those with lower self-concept. The self-concept of the students, which they found that students who have high academic self-concept have higher grades because they are more motivated to perform well in school (Tavani \& Losh, 2003). However, students who have low self-concept avoid school tasks because they consider these as threats, which led them to have poor performance.

The study of Othman and Leng (2011) shows that there is a weak significant relationship between selfconcept and academic achievement among the students, a weak and negative significant relationship between students' intrinsic motivation and their academic achievement and a weak significant and negative relationship between students' self-determination and their academic achievement. However, previous studies indicated that academic achievement among students is influenced by several important factors, which directly and indirectly related to self-concept, intrinsic motivation, and self-determination. Apart from such a relationship, there are other factors considered to be salient but relevant and contribute to the success of the students' performance. These factors include the role of significant others, such as family support, teachers' attitude, and peers understanding, which have been found by this research.

\section{Test of Significant Difference}

This section presents the data analysis on the test of significant difference in the self-concept of the respondents based on their gender. Table 7 presents the results of the test. 
Table 7. Significant Difference on the Self-Concept of the Respondents based on Gender

\begin{tabular}{|c|c|c|c|c|c|c|}
\hline Self-Concept & $\begin{array}{l}\text { Source of } \\
\text { Difference }\end{array}$ & Mean & StDev & $\begin{array}{c}\text { Computed } \\
\text { t-value }\end{array}$ & p-value & Decision \\
\hline \multirow{2}{*}{ A. Learned } & Male & 2.76 & 0.650 & \multirow{2}{*}{0.463} & \multirow{2}{*}{0.644} & \multirow{2}{*}{ Do not Reject Ho } \\
\hline & Female & 2.72 & 0.654 & & & \\
\hline \multirow{2}{*}{ B. Organized } & Male & 2.80 & 0.622 & \multirow{2}{*}{0.204} & \multirow{2}{*}{0.839} & \multirow{2}{*}{ Do not Reject Ho } \\
\hline & Female & 2.78 & 0.656 & & & \\
\hline \multirow{2}{*}{ C. Dynamic } & Male & 2.99 & 0.761 & \multirow{2}{*}{0.967} & \multirow{2}{*}{0.335} & \multirow{2}{*}{ Do not Reject Ho } \\
\hline & Female & 2.87 & 0.806 & & & \\
\hline
\end{tabular}

*Significant level at 0.05 (two-tailed) at $d f=181$

Table 8. Significant Relationship Between Self-Concept and Academic Performance in Mathematics

\begin{tabular}{lcccc}
\hline \multicolumn{1}{c}{ Variables } & n & Pearson r & p-value Decision Remarks \\
\hline A. Self-concept is Learned and Academic Performance in Math & 183 & $0.296^{* *}$ & 0.000 & Reject Ho Significant \\
\hline B. Self-concept is Organized and Academic Performance in Math & 183 & $0.398^{* *}$ & 0.000 & Reject Ho Significant \\
\hline C. Self-concept is Dynamic and Academic Performance in Math & 183 & $0.343^{* *}$ & 0.000 & Reject Ho Significant \\
\hline
\end{tabular}

** Correlation is significant at the 0.01 level (2-tailed).

It can be seen in Table 7 that in all areas of the self-concept there were no significant differences found on the level of self-concept of the respondents concerning their gender based on the 0.05 level of significance using a two-tailed test. The following are the results of the test: self-concept is learned $(t=0.463, p=0.644)$, selfconcept is organized $(\mathrm{t}=0.204, \mathrm{p}=0.839)$ and self-concept is dynamic $(\mathrm{t}=0.967, \mathrm{p}=0.335)$ which revealed that the null hypothesis is not rejected since the p-values of the three variables on self-concept are all greater than 0.05 level of significance. The data revealed that there are no differences between the perceptions of the male and the female respondents on the three areas of self-concept. The differences that exist between the means of the self-concept the respondents based on gender are not statistically different. This implies that the selfconcept of the respondents are of the same level when gender is considered.

Tella (2010) supported the results of this study when they investigated the relationship of self-concept and Math achievement of senior secondary school students, which revealed that there was no significant difference in gender for Math self-concept.

However, this finding is contrary to the findings of Egorova (2016), which analyzed the sex differences of the students in self-concept and academic performance in Math among the Russian high school students, which revealed that there was a sex difference in the mathematics achievement of the students wherein girls had higher grades compared to boys. Moreover, girls had higher self-concept than boys on Math tests, but boys perform better in the test compared to their counterparts.

\section{Test of Significant Relationship}

This part reveals the results on the test of a significant relationship between self-concept and academic performance of the respondents in Mathematics. Table 8 shows the details of the results, which used Pearson $r$ in testing the relationship between the variables.

It can be observed that there were significant relationships between all the areas of self-concept and the respondents' academic performance in Mathematics. As to the self-concept is learned, there is a weak positive correlation between the self-concept as learned and the academic performance of the respondents with the computed r-value of 0.296 and a p-value $<0.01$ means that the null hypothesis is rejected. Thus, there exists a significant relationship between the self-concept as learned and the academic performance of the respondents. On the other hand, the computed r-value of 0.398 between self-concept as organized and academic performance means that there is a weak positive correlation between these variables and the $p$-value $<0.01$ implies that the invalid speculation is rejected showing that there is a significant relationship between these variables. Whereas, the computed r-value of 0.343 between self-concept as dynamic and academic performance implies that there is a weak positive correlation between these variables and a $\mathrm{p}$-value $<0.01$. This suggests that there is a significant relationship between the self-concept as dynamic and the academic performance of the respondents in Mathematics.

This finding is steady with the discoveries of Dramanu and Balarabe (2013), which revealed that there was a significant relationship between self-concept and the academic performance of the 1470 junior high school students in Ghana. 
Awan et al.'s (2011) study examined the achievement and its relationship with achievement motivation and self-concept. The results revealed that achievement motivation and self-concept are mostly identified with scholastic accomplishment. Huge sex contrasts were found, which were supportive of young ladies. It was recommended that instructors must utilize inspirational techniques to include understudies in scholarly exercises for improving their evaluations.

The study of Pietsch et al. (2003) determined that the relationship between self-concept, self-efficacy, and performance in mathematics was examined among high school students. Self-efficacy beliefs, however, were identified as most highly related to performance in mathematics and percentages.

The study of Seaton et al. (2014) suggests that motivated students and those with high academic selfconcepts perform better academically. Although substantial evidence supports a reciprocal relationship between academic self-concept and achievement, there is less evidence supporting a similar relation between achievement goal orientations and achievement.

\section{CONCLUSIONS}

Based on the evidence presented in the data, it can be concluded that male and female students have the same level of self-concept when it comes to learning Mathematics. The self-concept of the students needs to be improved because their self-concept has a contribution to their performance.

\section{RECOMMENDATIONS}

The researchers recommend that the proposed mathematics performance enhancement plan, which is geared towards addressing issues identified in this study, be highly recommended for adoption and evaluation.

\section{Disclosure statement}

No potential conflict of interest was reported by the authors.

\section{Notes on contributors}

Emerson Peteros - College of Education, Cebu Technological University, Cebu City, Philippines.

Antonietta Gamboa - Department of Education - Province of Cebu, Cebu, Philippines.

Jonathan O. Etcuban - College of Education, Cebu Technological University, Cebu City, Philippines.

Aahron Dinauanao - University of Southern Philippines Foundation, Cebu City, Philippines.

Regina Sitoy - College of Education, Cebu Technological University, Cebu City, Philippines.

Redjie Arcadio - Cebu Technological University, Cebu City, Philippine.

\section{REFERENCES}

Ajogbeje, J. O. (2010). Self-concept as predictor of mathematics achievement among secondary school students in Ado-Ekiti, Nigeria. Nigerian Journal of Guidance and Counselling, 15(1). https://doi.org/10.4314/njgc.v15i1.64658

Awan, R. U. N., Noureen, G., \& Naz, A. (2011). A study of relationship between achievement motivation, selfconcept, and achievement in English and Mathematics at secondary level. International Education Studies, 4(3), 72-79. https://doi.org/10.5539/ies.v4n3p72

Bandura, A., Barbaranelli, C., Caprara, G. V., \& Pastorelli, C. (2001). Self-efficacy beliefs as shapers of children's aspirations and career trajectories. Child Development, 72(1), 187-206. https://doi.org/10.1111/1467-8624.00273

Beilock, S. L., Gunderson, E. A., Ramirez, G., \& Levine, S. C. (2010). Female teachers' math anxiety affects girls' math achievement. Proceedings of the National Academy of Sciences, 107(5), 1860-1863. https://doi.org/10.1073/pnas.0910967107

Capuno, R., Necesario, R., Etcuban, J. O., Espina, R., Padillo, G., \& Manguilimotan, R. (2019). Attitudes, Study Habits, and Academic Performance of Junior High School Students in Mathematics. International Electronic Journal of Mathematics Education, 14(3), 547-561. https://doi.org/10.29333/iejme/5768 
Cheryan, S., Master, A., \& Meltzoff, A. N. (2015). Cultural stereotypes as gatekeepers: Increasing girls' interest in computer science and engineering by diversifying stereotypes. Frontiers in Psychology, 6, 49. https://doi.org/10.3389/fpsyg.2015.00049

Correll, S. J. (2001). Gender and the career choice process: The role of biased self-assessments. American Journal of Sociology, 106(6), 1691-1730. https://doi.org/10.1086/321299

Cvencek, D., Kapur, M., \& Meltzoff, A. N. (2015). Math achievement, stereotypes, and math self-concepts among elementary-school students in Singapore. Learning and Instruction, 39, 1-10. https://doi.org/10.1016/j.learninstruc.2015.04.002

Cvencek, D., Meltzoff, A. N., \& Greenwald, A. G. (2011). Math-gender stereotypes in elementary school children. Child Development, 82(3), 766-779. https://doi.org/10.1111/j.1467-8624.2010.01529.x

Delpit, L. (2006). Lessons from teachers. Journal of Teacher Education, 57(3), 220-231. https://doi.org/10.1177/0022487105285966

Dramanu, B. Y., \& Balarabe, M. (2013). Relationship between academic self-concept and academic performance of junior high school students in Ghana. European Scientific Journal, ESJ, 9(34). Retrieved from http://bit.ly/2wQKux7

Egorova, M. S. (2016). Sex differences in mathematical achievement: Grades, national test, and selfconfidence. Psychology in Russia, 9(3), 4. https://doi.org/10.11621/pir.2016.0301

Else-Quest, N. M., Hyde, J. S., \& Linn, M. C. (2010). Cross-national patterns of gender differences in mathematics: A meta-analysis. Psychological Bulletin, 136(1), 103. https://doi.org/10.1037/a0018053

Farrington, C. A., Roderick, M., Allensworth, E., Nagaoka, J., Keyes, T. S., Johnson, D. W., \& Beechum, N. O. (2012). Teaching Adolescents to Become Learners: The Role of Noncognitive Factors in Shaping School Performance--A Critical Literature Review. Consortium on Chicago School Research. 1313 East 60th Street, Chicago, IL 60637. Retrieved from http://bit.ly/2Ifm5Ik

Ganley, C. M., Mingle, L. A., Ryan, A. M., Ryan, K., Vasilyeva, M., \& Perry, M. (2013). An examination of stereotype threat effects on girls' mathematics performance. Developmental Psychology, 49(10), 1886. https://doi.org/10.1037/a0031412

Gbollie, C., \& Keamu, H. P. (2017). Student academic performance: The role of motivation, strategies, and perceived factors hindering Liberian junior and senior high school students learning. Education Research International, 2017. https://doi.org/10.1155/2017/1789084

Grissom, J. B. (2004). Age \& achievement. Education Policy Analysis Archives, $12,49$. https://doi.org/10.14507/epaa.v12n49.2004

Guay, F., Ratelle, C. F., Roy, A., \& Litalien, D. (2010). Academic self-concept, autonomous academic motivation, and academic achievement: Mediating and additive effects. Learning and Individual Differences, 20(6), 644-653. https://doi.org/10.1016/j.lindif.2010.08.001

Hannover, B., \& Kessels, U. (2004). Self-to-prototype matching as a strategy for making academic choices. Why high school students do not like math and science. Learning and Instruction, 14(1), 51-67. https://doi.org/10.1016/j.learninstruc.2003.10.002

Hyde, J. S., \& Mertz, J. E. (2009). Gender, culture, and mathematics performance. Proceedings of the National Academy of Sciences, 106(22), 8801-8807. https://doi.org/10.1073/pnas.0901265106

Kamoru, U., \& Ramon, O. G. (2017). Influence of self-concept, study habit, and gender on attitude and achievement of secondary school students in mathematics. Journal for Leadership and Instruction, 16(1), 49-52. Retrieved from http://bit.ly/2XD0cb0

Khalaila, R. (2015). The relationship between academic self-concept, intrinsic motivation, test anxiety, and academic achievement among nursing students: Mediating and moderating effects. Nurse Education Today, 35(3), 432-438. https://doi.org/10.1016/j.nedt.2014.11.001

Kvedere, L. (2012). Mathematics self-concept of the 9th-grade students in Latvia. Procedia-Social and Behavioral Sciences, 46, 3380-3384. https://doi.org/10.1016/j.sbspro.2012.06.070

Lee, C. Y., \& Kung, H. Y. (2018). Math self-concept and mathematics achievement: Examining gender variation and reciprocal relations among junior high school students in Taiwan. Eurasia Journal of Mathematics, Science and Technology Education, 1239-1252. https://doi.org/10.29333/ejmste/82535 
Martin, P. Y., \& Jackson, S. (2002). Educational success for children in public care: Advice from a group of high achievers. Child \& Family Social Work, 7(2), 121-130. https://doi.org/10.1046/j.13652206.2002.00240.x

Meece, J. L., Glienke, B. B., \& Burg, S. (2006). Gender and motivation. Journal of School Psychology, 44(5), 351-373. https://doi.org/10.1016/j.jsp.2006.04.004

Nagy, G., Watt, H. M., Eccles, J. S., Trautwein, U., Lüdtke, O., \& Baumert, J. (2010). The development of students' mathematics self-concept in relation to gender: Different countries, different trajectories?. Journal of Research on Adolescence, 20(2), 482-506. https://doi.org/10.1111/j.1532-7795.2010.00644.x

Nosek, B. A., Banaji, M. R., \& Greenwald, A. G. (2002). Math= male, me= female, therefore $\operatorname{math} \neq$ me. Journal of Personality and Social Psychology, 83(1), 44. https://doi.org/10.1037/0022-3514.83.1.44

Othman, N., \& Leng, K. B. (2011). The relationship between self-concept, intrinsic motivation, selfdetermination, and academic achievement among Chinese primary school students. International Journal of Psychological Studies, 3(1), 90. https://doi.org/10.5539/ijps.v3n1p90

Pajares, F., \& Schunk, D. H. (2001). Self-beliefs and school success: Self-efficacy, self-concept, and school achievement. Perception, 11, 239-266. Retrieved from http://bit.ly/2Kf1ohK

Pietsch, J., Walker, R., \& Chapman, E. (2003). The relationship among self-concept, self-efficacy, and performance in mathematics during secondary school. Journal of Educational Psychology, 95(3), 589. https://doi.org/10.1037/0022-0663.95.3.589

Pintrich, P. R. (2000). Multiple goals, multiple pathways: The role of goal orientation in learning and achievement. Journal of Educational Psychology, 92(3), 544. https://doi.org/10.1037/0022-0663.92.3.544

Preckel, F., Goetz, T., Pekrun, R., \& Kleine, M. (2008). Gender differences in gifted and average-ability students: Comparing girls' and boys' achievement, self-concept, interest, and motivation in mathematics. Gifted Child Quarterly, 52(2), 146-159. https://doi.org/10.1177/0016986208315834

Priess-Groben, H. A., \& Lindberg, S. M. (2018). Gender intensification. Encyclopedia of Adolescence, $1552-$ 1561. https://doi.org/10.1007/978-3-319-33228-4_391

Ryan, A. M., \& Patrick, H. (2001). The classroom social environment and changes in adolescents' motivation and engagement during middle school. American Educational Research Journal, 38(2), 437-460. https://doi.org/10.3102/00028312038002437

Seaton, M., Parker, P., Marsh, H. W., Craven, R. G., \& Yeung, A. S. (2014). The reciprocal relations between self-concept, motivation, and achievement: juxtaposing academic self-concept and achievement goal orientations for mathematics success. Educational Psychology, 34(1), 49-72. https://doi.org/10.1080/01443410.2013.825232

Sincero, S. M. (2012). Self-concept theory. Retrieved from http://bit.ly/2KrXjqG

Spencer, S. J., Steele, C. M., \& Quinn, D. M. (1999). Stereotype threat and women's math performance. Journal of Experimental Social Psychology, 35(1), 4-28. https://doi.org/10.1006/jesp.1998.1373

Tavani, C. M., \& Losh, S. C. (2003). Motivation, self-confidence, and expectations as predictors of the academic performances among our high school students. Child Study Journal, 33(3), 141-152. Retrieved from http://bit.ly/2MYqV11

Tella, A. (2007). The impact of motivation on student's academic achievement and learning outcomes in mathematics among secondary school students in Nigeria. Eurasia Journal of Mathematics, Science \& Technology Education, 3(2), 149-156. https://doi.org/10.12973/ejmste/75390

Timmerman, H. L., Van Luit, J. E., \& Toll, S. W. (2017). The relation between math self-concept, test and math anxiety, achievement motivation, and math achievement in 12 to 14-year-old typically developing adolescents. https://doi.org/10.25115/psye.v9i1.465

Tully, D., \& Jacobs, B. (2010). Effects of single-gender mathematics classrooms on self-perception of mathematical ability and post-secondary engineering paths: An Australian case study. European Journal of Engineering Education, 35(4), 455-467. https://doi.org/10.25115/psye.v9i1.465

Zimmerman, B. J. (2013). Theories of self-regulated learning and academic achievement: An overview and analysis. In Self-regulated learning and academic achievement (pp. 10-45). Routledge. https://doi.org/10.4324/9781410601032 